\title{
A Late-Miocene Yuli belt? New constraints on the eastern Central Range depositional ages
}

\author{
Lucas Mesalles ${ }^{1}$, Yuan-Hsi Lee ${ }^{1, *}$, Ting-Cheng Ma ${ }^{1}$, Wan-Ling Tsai ${ }^{1}$, Xi-Bin Tan ${ }^{2}$, and Hao-Yang Lee ${ }^{3}$ \\ ${ }^{1}$ Department of Earth and Environmental Sciences, National Chung-Cheng University, Chiayi County, Taiwan \\ ${ }^{2}$ Institute of Geology, China Earthquake Administration, Beijing, China \\ ${ }^{3}$ Institue of Earth Sciences, Academic Sinica, Taipei City, Taiwan
}

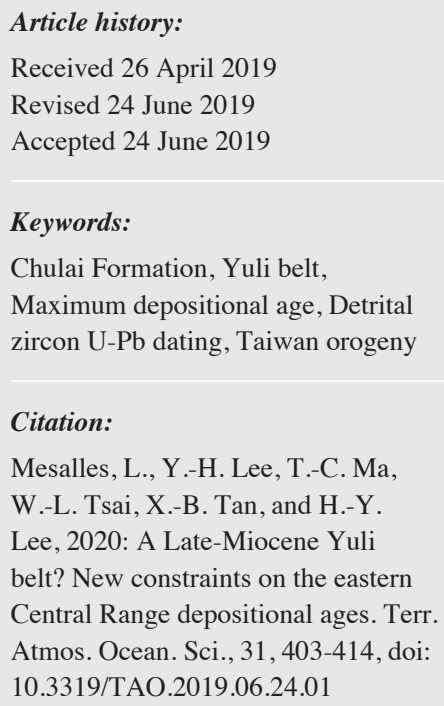

\begin{abstract}
In Taiwan's Central Range mountains, fundamental constraints on depositional ages and the timing of deformation and metamorphism remain a problematic issue preventing a consensual chronology of orogenic events to be established. In this contribution, we report detrital zircon U-Pb detrital ages for the Chulai Formation, the easternmost strip of metamorphic sediments depositionally overlying the metamorphic, high-pressure Yuli belt. We demonstrate that the maximum depositional age of this unit is $11.2 \pm 0.2 \mathrm{Ma}$ (Upper Miocene, Tortonian), making it the youngest pervasively deformed and metamorphosed unit of the Central Range. Detrital zircon ages suggest an almost exclusively continental origin of the sediments similar to the Yuli belt's matrix detrital age zircon spectra. Sedimentary relationships and structural considerations indicate that the Chulai Formation underwent essentially the same deformation history as the underlying Yuli belt, and thus the maximum depositional age of 11.2 $\pm 0.2 \mathrm{Ma}$ is interpreted as the upper limit for the start of pervasive deformation of the eastern Central Range geological units. When considering the existing geochronological constraints on the metamorphism, we argue that the timing for the Cenozoic metamorphism of the Taiwan orogen is likely to be $\sim 6-8 \mathrm{Ma}$.
\end{abstract}

\section{INTRODUCTION}

Short-duration orogenic metamorphism ( 1 - 10 Myrs) is increasingly recognised in the geological record worldwide (Viete and Lister 2017) and is thought to reflect transient crustal condition rather than geologically prevalent physico-chemical conditions (e.g., Chu et al. 2017; Viete et al. 2018). The active Taiwan mountain belt is one of the most rapid convergent collisional plate boundaries $\left(\sim 82 \mathrm{~mm} \mathrm{yr}^{-1}\right.$; $\mathrm{Yu}$ et al. 1997) with surface uplift rates reaching up to $\sim 23 \mathrm{~mm} \mathrm{yr}^{-1}$ (Ching et al. 2011), and is a paradigmatic example of a rapidly exhuming orogen (e.g., Willett et al. 2003; Hsu et al. 2016). Notably, the glaucophane bearing highpressure metamorphic rocks of the Yuli belt in the Taiwan's Central Range have been buried to depth of $35-50 \mathrm{~km}$ (Beyssac et al. 2008; Tsai et al. 2013; Keyser et al. 2016; Baziotis et al. 2017), and started to be exhumed in the latest Miocene to Pliocene times (Liu et al. 2001; Lee et al. 2006; Mesalles et al. 2014). However, opposing evidences on the

\footnotetext{
* Corresponding author

E-mail:leeyuanhsi@gmail.com
}

exact timing of metamorphism exist in the published literature. On the one hand ${ }^{40} \mathrm{Ar} /{ }^{39} \mathrm{Ar}$ ages on amphibole in the Yuli's HP metamorphic blocks of 12.2 $\pm 0.5 \mathrm{Ma}$ (Lo and Yui 1996) have been argued to support a Middle-Miocene onset of mountain building and metamorphism (Chen et al. 2019). On the other hand one Lu-Hf age of $5.1 \pm 1.7 \mathrm{Ma}$ on garnet (Sandmann et al. 2015) argue for a later timing for peak metamorphic conditions. In a more recent contribution, Lo et al. (2020) presents a robust $9.1 \pm 0.1$ Ma muscovite ${ }^{40} \mathrm{Ar} /{ }^{39} \mathrm{Ar}$ age in or next some of the Yuli HP blocks and interpret it as the timing for the early retrograde path.

Depositional ages of protoliths in metamorphic belts are the single fundamental constraint providing an unequivocal upper bound for the timing of metamorphism. Detrital zircon $\mathrm{U}-\mathrm{Pb}$ dating is particularly suited for this purpose given the ubiquity of zircon minerals and the relative ease to date of large number of grains. In the cases of highly deformed terrains with poor fossil preservation, it might turn out to be the only technique providing reasonable depositional age constraint. Zircon U-Pb dating has mostly been applied in 
Taiwan to elucidate pre-Cenozoic histories (Lan et al. 2009; Yui et al. 2009, 2012), in Cenozoic sediments of South China Sea passive margin affinity (Kirstein et al. 2010b; Shao et al. 2017), on orogeny-derived sediments (Kirstein et al. 2010a) and on present day river sediments (Deng et al. 2017). Only a limited number studies have used this technique for depositional purposes in deformed sediments in the Central Range (Chen et al. 2016, 2017; Chung et al. 2018). Chen et al. (2017) contributed with a crucial mid-Miocene protolith crystallisation age for the HP ultramaphic blocks in the Yuli belt, resulting on a younger depositional age for this metamorphic belt as whole, previously thought to be Late Mesozoic (e.g., Lo and Yui 1996; Yui et al. 2012), and now known to be post-Mid-Miocene $(<15.6 \pm 0.3 \mathrm{Ma})$.

This paper reports new detrital zircon U-Pb ages of six samples from the Chulai Formation, a narrow unit of marine sediments conventionally mapped as Eocene strata (Ho 1986, 1988) located in the southeastern margin of the Central Range's metamorphic core (Fig. 1). Our results provide a consistent maximum depositional age markedly different from the previously assigned Eocene age, bringing a new upper time limit to the time of deformation and metamorphism. Comparison with published zircon detrital suites and other geochronological constraints in the Central Range units constrain potential genetic relationships and allow discussion on the implications of these findings for the Central Range's orogenic development and metamorphism.

\section{REGIONAL GEOLOGY AND STUDY AREA}

The Taiwanese mountain belt is the result of the subduction of the South-China Sea oceanic crust below the Philippine Sea plate, arrival of the continental passive margin to the Manila trench, subsequent shortening of the forearc basin and final collision of the continental material with the Luzon volcanic arc (Ho 1988). Our study area is located in the eastern margin of the Central Range, the geological province supporting the island's main topography. The Central Range can be subdivided into three main geological provinces: the Permian-Cretaceous basement of the Tailuko belt, the Miocene Yuli belt formed by a dominantly pelitic matrix embedding rare meta-igneous and high-pressure mafic rocks, and the up to green-schist grade Eocene to Mid-Miocene passive margin sedimentary cover (Biq 1974; Ho 1988; Chen et al. 2017). Traditionally the mapped extent of the Eo-Miocene sediments comprises all the western divide, the high mountain ridges, and an additionally strip in the easternmost, low-lying part of the eastern Central Range. The latter is the subject of the present paper (Fig. 1).

Informally referred as the Eastern Slate belt, this geological unit was correlated to the western Eocene series based solely on lithological similarities (Ho 1988;) since the first known accounts (Ooe et al. 1939), although no diagnostic fossil was reported. Later maps maintained the

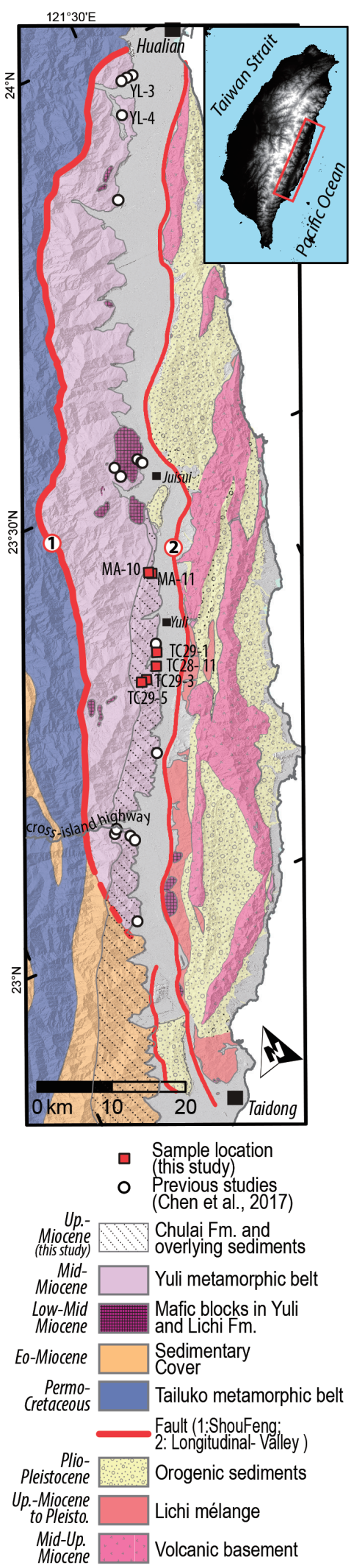

Fig. 1. Eastern Central Range geological map with this study's and Chen et al. (2017) sample location [note that Chen et al. (2017) sample localities were manually digitalised]. Geology based on Stanley et al. (1981) and Chen et al. (2017). Inset: Taiwan's topography with main map extent indicated as a red rectangle. 
Eocene depositional age (CGS 1974, 1978; Ho 1988; Chen et al. 2000) initially as part of the Hsinkao Formation and later as the renamed Pilushan Formation. However some recent contributions assigned a Miocene age (Chen 2016; Lin and Chen 2016), and even suggested it is part of the Yuli belt (Keyser et al. 2016; Chen et al. 2017).

The only published detailed lithostratigraphic and structural study of the eastern Central Range is provided by Stanley et al. (1981). Stanley et al. (1981) distinguishes the Chulai Formation and the interpreted eastern equivalent of the Eocene Hsinkao Formation, the latter lying on a stratigraphically younger position. Both are described to be sitting on an unfaulted contact on top of the Yuli belt. The Chulai Formation was defined as a quartz-mica-rich phyllite with massive $30 \mathrm{~cm}$ to $3 \mathrm{~m}$ thick quartzo-feldspathic greywacke beds, with a lack of dark-grey phyllite and thin $(<1 \mathrm{~m})$ beds of metasandstone, characteristic of the eastern Hsinkao Formation, and a finer grained nature of the Chulai Formation's phyllites and lack of quartz veins when compared to Yuli belt highly veined black-schists (Stanley et al. 1981). Importantly, the Chulai Formation is described as bounded by two depositional contacts with the underlying Yuli belt units and overlying Hsinkao Formation sediments, and interpreted as forearc sediments partly deposited on top of the Manila trench accretionary wedge before or during pervasive deformation (i.e., six generation of folding and schistosity; Stanley et al. 1981). Stanley et al. (1981)'s maps the Chulai Formation all the way from the southern Crossisland highway to around Juisui area, and only recognize the Hsinkao Formation in some localized patches north of the southern Cross-island highway, while south of it, the Hsinkao Formation is mapped as in direct contact with the Yuli belt units (see Fig. 2 in Stanley et al. 1981). They interpret the depositional contact below the Chulai Formation as being an angular unconformity based on the various Yuli belt facies observed below the contact along strike.

Raman spectroscopy of carbonaceous material in the Chulai and eastern Hsinkao Formations indicates a peak metamorphic temperature of $\sim 370^{\circ} \mathrm{C}$ (Beyssac et al. 2007). Elsewhere in the eastern Central Range rocks present presumably overprinted green schist facies metamorphic mineral assemblage (Chen et al. 1983; and reference within it). The Yuli belt contains mafic blocks reaching blueschist metamorphic facies $\left(10-12 \mathrm{kbar} / 550^{\circ} \mathrm{C}\right.$, Beyssac et al. 2008) of oceanic (Liou 1981) and island arc (Jahn et al. 1981; Sun et al. 1998) affinity. The Yuli's high-pressure metamorphism is often considered to be limited to the mafic blocks (Yang and Wang 1985; Lin 1999; Beyssac et al. 2008) with no diagnostic HP minerals in the dominant surrounding metapelites, implying a post-peak metamorphic conditions tectonic emplacement of the meta-volcanic blocks. However recent P-T estimates $\left(15.5\right.$ - $17 \mathrm{kbar} / \sim 540^{\circ} \mathrm{C}$; Keyser et al. 2016) in a garnet bearing metapelite of the Yuli matrix adjacent to the HP blocks suggests a pre-metamorphic juxtaposi- tion of different lithologies followed by deep tectonic burial.

Recent dating of one the Yuli belt's blueschist bodies (Tamayen block; Chen et al. 2017) have fundamentally changed our understanding of the age and nature of metamorphism through the dating of the high-pressure rocks protolith age to Mid-Miocene times (three samples weighted mean of $15.6 \pm 0.3 \mathrm{Ma} ; n=62$ ). A consequence of this discovery is that deposition of the enclosing Yuli belt sediments and subsequent metamorphism necessarily post-dates the block's crystallisation age, perhaps providing the single most solid upper bound age for mountain building and metamorphic processes initiation to date. The present paper further contributes to improve this upper-bound age of metamorphism and mountain building through constraining the maximum depositional age of the overlying Chulai Formation.

\section{SAMPLING AND ANALYTICAL METHODS}

The LA-ICPMS facilities (Agilent 7500s quadruple inductively coupled plasma mass spectrometer equipped with a New Wave UP-213 laser ablation system) at the National Chung Cheng University, Department of Earth and Environmental Science (Chiayi, Taiwan), was used to date 41 to 186 grains in six Chulai Formation samples. Cathodoluminescence and secondary electron microphotographs were taken for the dated grains using the Scanning Electron Microprobe facility (JEOL JSM T-100) at the Institute of Earth Science, Academia Sinica (Taipei, Taiwan).

LA-ICPMS's spot ablation is $\sim 40 \mu \mathrm{m}$ in diameter and $\sim 15 \mu \mathrm{m}$ in depth. Each analysis lasted 70 seconds followed by 60 seconds blank. Standard zircon samples used for calibration were GJ-1 (Jackson et al. 2004; weighted mean of $600.4 \pm 0.3 \mathrm{Ma}$ ) and Plešovice (Sláma et al. 2008; weighted mean of $337.1 \pm 0.4 \mathrm{Ma}$ ). Weighted mean values obtained during the time of analysis were of $600.7 \pm 1.8$ and $338.4 \pm$ 1.7 Ma for GJ-1 and Plešovice standards respectively.

Two to four kilograms of silt to coarse sandstone were sampled in two distinct field missions. The first sampling mission was carried out in the fall of 2011 and, after discovery of young ages in samples MA10 and MA11 (Fig. 1), a second sample mission was carried out in the fall of 2016 targeting the exact same outcrops yielding young zircon ages. Samples were crushed and processed using standard heavy mineral and magnetic separation techniques, subeuhedral to euhedral zircon grains with sizes between 96 - $500 \mu \mathrm{m}$ of all colours were selected in order increase the chances to capture datable, relatively young, populations.

Raw analytical data was treated using GLITTER 4.4.2 (GEMOC) software. Plots and statistical treatment of the data were computed using IsoplotR v.2.3 (Vermeesch $2018 \mathrm{~b}$ ). In this paper we utilize a cross-over point of 1.5 $\mathrm{Ga}$ between the use of ${ }^{207} \mathrm{~Pb} /{ }^{206} \mathrm{~Pb}$ ages (ages $<1.5 \mathrm{Ga}$ ) to ${ }^{206} \mathrm{~Pb} /{ }^{238} \mathrm{U}$ (ages $>1.5 \mathrm{Ga}$ ), as recommended by Spencer et al. (2016). Note that here we report the age density spectra 
using an adaptive Kernel Density Estimate (Fig. 2b) and not the commonly used Probability Density Plots (PDP) (e.g., Ludwig 1998) as PDP has been shown to yield inherent statistical inconsistencies (Vermeesch 2012).

To further quantitatively compare the relative (dis)similarity of zircon $\mathrm{U}-\mathrm{Pb}$ age spectra independently of sample size (i.e., number $\mathrm{n}$ of dated grains), we apply the multidimensional scaling method (Vermeesch 2018a) where (dis)similarity between samples is converted into a set of Euclidian coordinates allowing a graphical assessment of the disparity between a set of zircon ages suites; samples with similar spectra will plot close together while dissimilar samples will plot far apart. Here we adopt the approach provided by Vermeesch (2018b) where the statistical distance between two samples is calculated using the KolmogorovSmirnov statistics, which quantifies the maximum vertical difference between two cumulative age distribution step functions to identify the relative similarity. In practice, the input data includes all ages (error bars are not included) for a given sample or group of samples (e.g., grouped by geological unit). In our case we combine our own detrital zircon U-Pb ages (this study) with Chen et al. (2017)'s data to obtain a representative "map" of all Central Range geological formation's detrital signatures (Fig. 3). This approach has recently been successfully applied in regional provenance studies (Shao et al. 2017) and in global zircon dataset analysis (Barham et al. 2019).

\section{RESULTS}

LA-ICP-MS U-Pb zircon grain ages and analytical data of the six meta-sedimentary samples belonging to the Chulai Formation are provided in the supplementary materials (SM1). Kernel density estimates age spectra for this study's individual samples are provided in SM2. Individual sample kernel density plots of our analysed Chulai Formation samples yield similar spectra (SM2), with the exception of samples MA10 and MA11 which contain a distinct Upper Miocene age population (Figs. 2 and 4). In the following we present the combined zircon age spectra of thirteen samples from the Chulai Formation including seven samples from Chen et al. (2017) and compare them to the existing detrital zircon U-Pb spectra of other the Central Range units; we then focus on the young zircon population.

\subsection{Combined Age Spectra and Similarity Analysis}

Figure 2 shows the combined cumulative (Fig. 2a) and kernel density estimates (Fig. 2b) zircon U-Pb age spectra of the analysed samples as compared to the existing data in the Yuli belt and Eo-Oligocene sediments of the Hsuehshan Range (Chen et al. 2017). In all three geological units, at least $97 \%$ of the dated grains are pre-Cenozoic.

Yuli belt and Chulai Formation samples share the main
pre-Cenozoic density peaks (Fig. 2b) which include prominent peaks at $\sim 120-130, \sim 165-175, \sim 215-225, \sim 435$ - 445, 760 - 780, 1855 - 1865, and $\sim 2480-2490 \mathrm{Ma}$. On the other hand, Eo-Oligocene sediments' age spectra yield prominent peaks at $\sim 110-120, \sim 155-165, \sim 245$ - 255, 425 - 435, 960 - 970, 1865 - 1875, and 2525 - $2535 \mathrm{Ma}$. Additionally, there is a significant number of grains $(n=11 ; 1.0 \%)$ in the Chulai Formation samples older than $3000 \mathrm{Ma}$ (Meso-archean), not present in the Yuli belt but present in the Eo-Oligocene sediments $(n=3 ; 0.5 \%)$, although all three geological units contain grains older than $2500 \mathrm{Ma}$ (Archean), particularly the Yuli belt samples $(n=$ 47; 4.9\%).

Cenozoic peaks include the youngest peak at $\sim 10$ - 12 Ma present in both Yuli belt $(n=3 ; 0.3 \%$; samples YL-3 and YL-4 in Chen et al. 2017) and Chulai Formation sediments ( $n=18 ; 1.7 \%$; this study) (Fig. 2b). Other minor age population peaks in the Chulai Formation and Yuli's samples include $\sim 19$ - 21 and 23 - $26 \mathrm{Ma}$, the former being more prominent in the Chulai Formation and the latter more prominent in the Yuli belt. Eo-Oligocene samples, in the other hand, contain a significant $\sim 41-43 \mathrm{Ma}(n=13 ; 2.2 \%)$ peak which include the youngest dated zircon grains in that stratigraphic level (aside from one grain dated to $27.4 \pm 0.6$ Ma belonging to the Oligocene strata).

Finally, in order to systematically assess the (dis)similarity between the Chulai Formation, Yuli sediments and the other geological units of the Central Range were published detrital zircon U-Pb exists, we compute a non-metric multidimensional scaling plot (Fig. 3). Three clusters are recognised, Eocene and Oligocene, Yuli and Chulai Formation, and Mid-Late Miocene and Early Miocene, indicating similar detrital zircon U-Pb spectra within each cluster. Yuli and Chulai Formation plot particularly close to each other indicating a close correspondence in their detrital age spectra and both plot towards the Early Miocene and MidLate Miocene sediments locus at the right part of the nondimensional graph (Fig. 3). Both Yuli and Chulai Formation identify the Early Miocene sediments as their second closest neighbour (dashed line).

We would like to stress that the results reported above are subject to the right identification of the formation from which Chen et al. (2017)'s samples were taken. Reported data in Chen et al. (2017) is not geolocalized (i.e., no GPS coordinates provided). We exclusively relied on the geological unit assigned to each sample in Chen et al. (2017)'s supplementary material. Notably, Chen et al. (2017)'s westernmost two samples in the southern cross-island highway (Fig. 1) were identified in the original paper as belonging to the Yuli belt, however after discussion with the lead author of the paper (Chen, W.-S., personal communication, May 2019), those two samples were assigned to the Chulai Formation and were consequently included in the Chulai Formation for the computations presented above. 


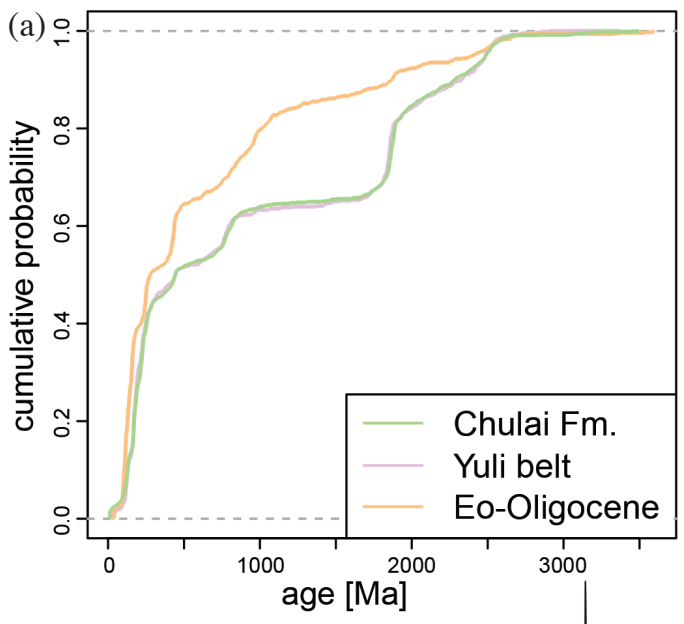

(b)

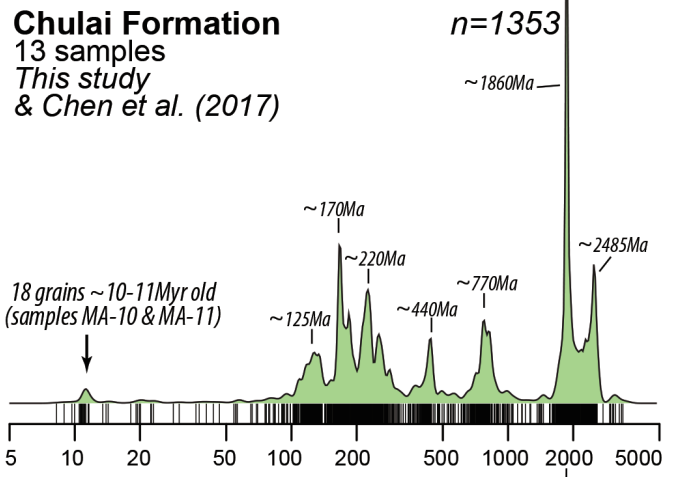

(c)

Yuli Belt

Chen et al. (2017)

$n=730$
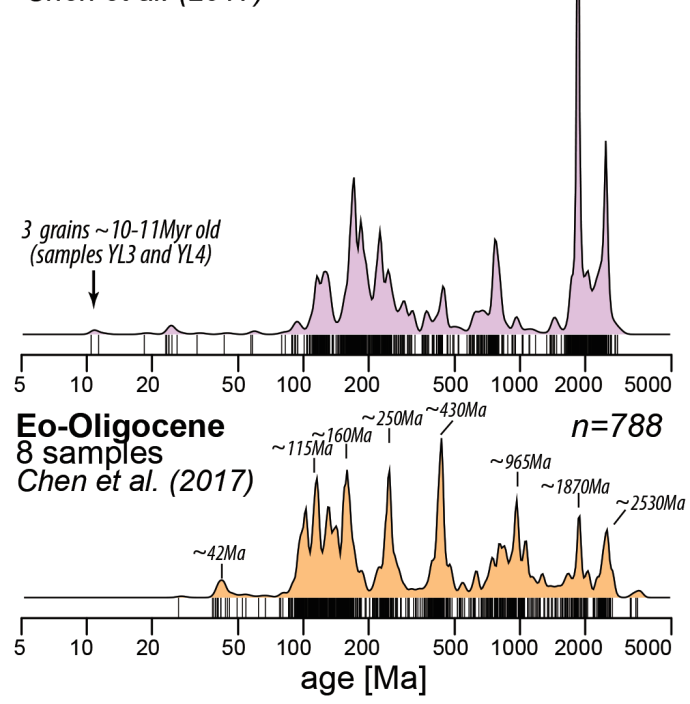

Fig. 2. Combined Zircon U-Pb detrital ages' cumulative age distribution (a) and area-normalized adaptive kernel densities estimates (b) plots from this study's samples and published data from the Chulai Formation, Yuli belt, and Eo-Oligocene sediments of western Central Taiwan (Chen et al. 2017). Ticks below the density curve represent the position of individual zircon grain ages. Estimates of the peaks central ages are displayed on top of each age density spike for the Chulai Formation and Eocene sediments. Note the practically undistinguishable cumulative age distribution and Kernel density plots of the Yuli belt and Chulai Formation samples. $n$ is the number of combined grains for each of the three geological units. Note that all Chen et al. (2017)'s samples on the southern Cross-Island highway are here considered as part of the Chulai Formation, conversely to what is stated in the original paper's supplementary material (see discussion in section 4.1). 


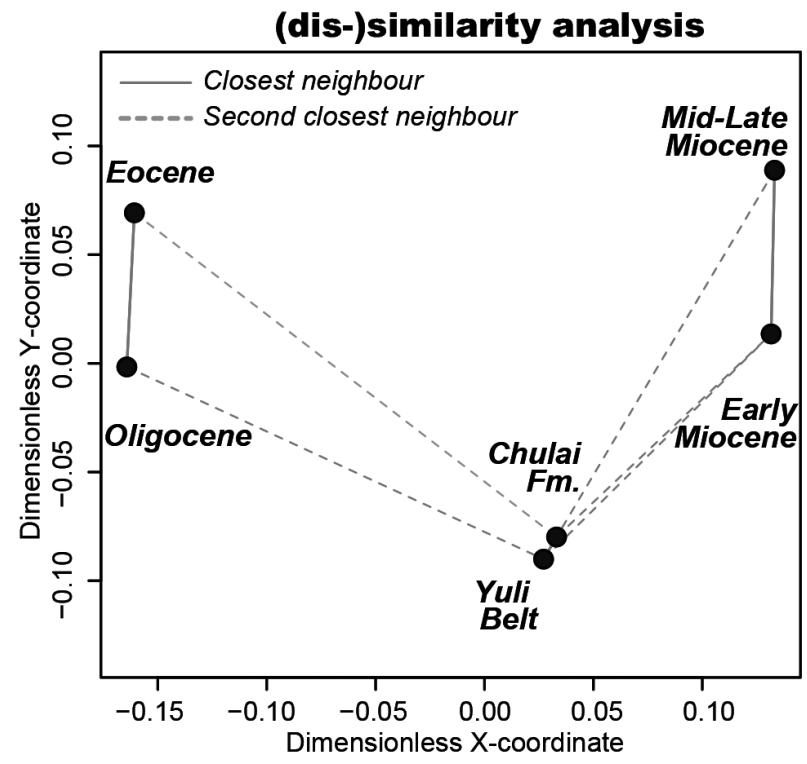

Fig. 3. Multidimensional scaling plot for the combined zircon detrital suites from Early Miocene, Mid-Late Miocene, Eocene, Oligocene, Yuli belt, and Chulai Formation (meta)sediments. Graphic distance (Euclidean) is proportional to the dissimilarity between each combined samples. Chulai Formation's samples include Chen et al. (2017) samples and this study's samples (same as in Fig. 2). All other samples are grouped by stratigraphic age from Chen et al. (2017).
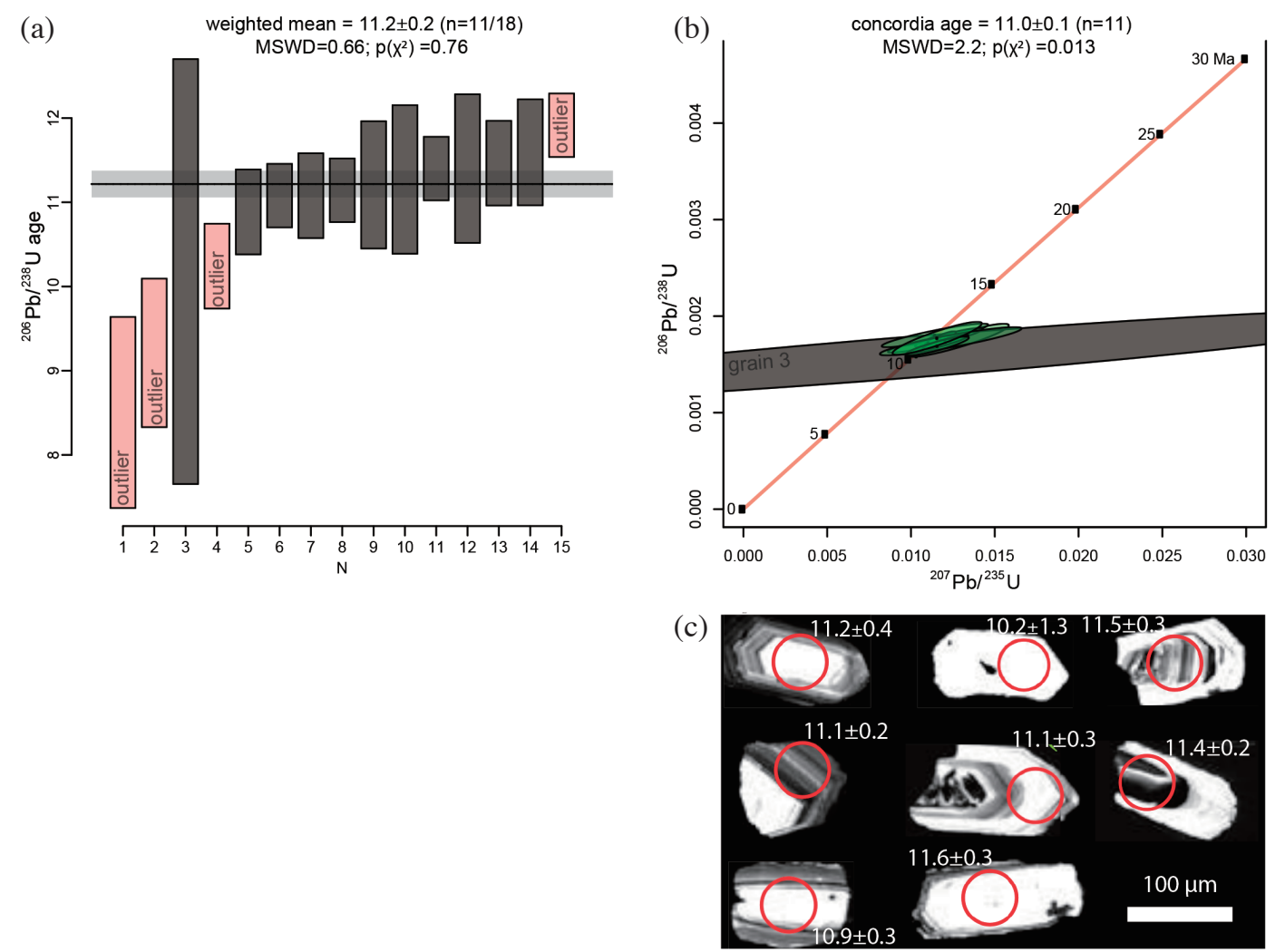

Fig. 4. MA11 and MA10 sample's (a) weighted mean of the young zircon population U-Pb ages, (b) concordia diagram of the zircon ages used in the weighted mean calculation, and (c) representative cathodoluminescence images selection of some of the young population grains from sample MA11 with red circles indicating LA-ICPMS laser ablation spot (refer to SM3 for complete cathodoluminescence images of sample MA-11 dated grains). 


\subsection{Upper Miocene Maximum Depositional Age}

Of all the Chulai formation dated samples only samples MA11 and MA10 yield coherent young population ( $n$ $=18 / 362 ; 5 \%)$. The young population's ${ }^{206} \mathrm{~Pb} /{ }^{238} \mathrm{U}$ zircon ages range between $8.5 \pm 0.6$ to $12.1 \pm 1.2 \mathrm{Ma}$, although most of the grains are between 10 and $12 \mathrm{Ma}$ (12 out of 18). From the eighteen (18) young zircon ages, fifteen (15) pass the discordance filter (i.e., -15 and $+5 \%$ discordance allowed between ${ }^{206} \mathrm{~Pb} /{ }^{238} \mathrm{U}$ and ${ }^{207} \mathrm{~Pb} /{ }^{235} \mathrm{U}$ ages). From the fifteen (15) ages, eleven (11) overlap within two-sigma. The weighted mean and $95 \%$ confidence interval of the remaining grain ages is $11.2 \pm 0.2 \mathrm{Ma}$ (Fig. 4). Note that the weighted mean is computed applying a random effects model and error includes the analytical uncertainty associated to the decay constants (Vermeesch 2018b).

The Mean Square of the Weighted Deviates (MSWD) is equal to 0.66 , well below the recommended limit value of 1.78 (calculated following the equation $1+2 \times[2 /(\mathrm{n}-1)]^{1 / 2}$ where $n$ is the number of dated grains; Spencer et al. 2016), indicating no overdispersion. Similarly, the $\mathrm{p}\left(\mathrm{x}^{2}\right)$ value of 0.76 is supportive of no overdispersion. This weighted mean seems robust as no Pb-loss can be inferred from the Concordia diagram (Fig. 4b). The weighted mean age is also consistent within error bars with the concordia age (11.0 \pm $0.1 \mathrm{Ma}$ ) (Fig. 4b).

Cathodoluminescence (CL) photomicrogrpahs of MA11's dated grains are provided in SM3. A representative selection of the younger population grains used in the weighted mean calculation is showed in Fig. 4c. The internal structure of the young population zircons is variable, from no structure with very high intensity luminescence to well-developed regularly spaced magmatic zoning or with rounded dark core with bright outer overgrowth. In general, the young grains do not show resorbed cores and are rather characterized by oscillatory zoning. Preliminary analysis of crystal core and rims yield similar ages, with no systematically younger rims (Fig. 4c; SM3).

\section{DISCUSSION}

In the following we first argue that, in light of our new results, the Chulai Formation and Yuli belt share a common sedimentary source, and given their maximum depositional age (MDA) and depositional contact separating them, likely belong to the same sedimentary succession having undergone at least partly similar deformation histories. It follows, the young population's age of samples MA11 and MA10 $(11.2 \pm 0.2 \mathrm{Ma}$; Fig. 4) provides a depositional age constraint for both the Chulai Formation and Yuli belt. Then we discuss the consequences of this finding for the Taiwan's orogenic history, particularly its metamorphic pathway.

\subsection{Linking the Chulai Formation to the Central Range Stratigraphy}

The combined kernel density estimates (Fig. 2b) and cumulative age distribution functions (Fig. 2a) of the Chulai Formation, Yuli belt and Hsuehshan Range's Eo-Oligocene sediments display a substantial difference between the Chulai Formation and the Eocene sediments, and a striking similarity between the Chulai Formation and Yuli belt spectra and cumulative curves.

Detrital zircon age spectra from the Chulai Formation and Eo-Oligocene strata, although sharing some pre-Cenozoic peaks, albeit at different proportions (i.e., peak height; note that the area below the kernel density estimate curve is normalized), display major differences, particularly in the Cenozoic grain age populations: (1) a $\sim 42 \mathrm{Ma}$ (Lutetian) density peak present in the Eo-Oligocene sediments and absent in the Chulai Formation; (2) a $\sim 11 \mathrm{Ma}$ (Tortonian) density peak present in the Chulai Formation and absent in the Eocene strata. Both populations represent the youngest zircon population in their respective stratigraphic level, display a symmetric age distribution and can be taken as the maximum depositional ages (Dickinson and Gehrels 2009; see discussion in next section). Furthermore, when systematically measuring the (dis)similarity between the considered stratigraphic levels, we observe that while Eocene and Oligocene age spectra plot close to each other in the nondimensional coordinates (Fig. 3), Chulai Formation falls relatively far away in the dimensionless plot towards the Early Miocene sediments locus (Fig. 3). Taken together, these evidences argue for a partly distinct sedimentary source and, more importantly, very distinct depositional age likely being Tortonian and Lutetian for the Chulai Formation and Eocene sediments respectively. This is at odds with the commonly Eocene age (Hsinkao or Pilushan Formation) assigned to the Chulai Formation sediments (e.g., Chen et al. 2000).

On the contrary, detrital zircon age spectra from the Chulai Formation and Yuli belt are strikingly similar (Figs. $2 b-c)$. Not only the pre-Cenozoic peaks are matching, and at similar proportions, but also the less prominent Neogene peaks are mostly corresponding (i.e., $\sim 11$ and $\sim 19$ - $26 \mathrm{Ma}$ grain populations). The multidimensional scaling plot (Fig. 3) appears to confirm the very similar detrital-age fingerprint with a very close position between the Chulai Formation and the Yuli belt. While these pieces of evidences do back a similar provenance and age of deposition, there are some minor differences. One main noticeable feature do differentiate the zircon age spectrums of the Chulai Formation and Yuli belt strata: the $>3000$ Ma grain population existent in the Chulai Formation and absent in the Yuli belt. Nevertheless Miocene sediments in Central Taiwan do contain few grains older than $>3000 \mathrm{Ma}(n=3 ; 0.5 \%$; Chen et al. 2017), and thus the fact that they are not found in the 
Yuli belt may possibly be linked to a bias in the selected dated grains, as Neo-archean (2500 - $2800 \mathrm{Ma}$ ) are well represented in the Yuli belt, although a change in the source area ages cannot be discarded.

\subsection{Chulai Formation Maximum Depositional Age}

Samples MA10 and MA11 yield a youngest concordant grain population weighted mean age of $11.2 \pm 0.2 \mathrm{Ma}$ (Fig. 4a). This age can be considered the maximum depositional age (MDA) as defined by (Dickinson and Gehrels 2009), where the youngest distinct and coherent population (i.e., not belonging to an age continuum) constrains the stratigraphic age's upper bracket. Zircon CL images of the young population grains mostly show an oscillatory zoning indicating a probable magmatic origin (Fig. 4c) with a potentially metamorphic overgrowth limited to a very thin $(<5 \mu \mathrm{m})$ rare outer rim (see also SM3), consistent with relatively low $\left(<400^{\circ} \mathrm{C}\right)$ maximum metamorphic temperatures where zircon growth has been shown to be limited (Kohn and Kelly 2017). Whether the young zircon population is cogenetic (i.e., syndepositional volcanism) is difficult to assess with our data but a final stage South China Sea rifting magmatic event spanning 23 to $8 \mathrm{Ma}$ has been described elsewhere (Chung et al. 1994; Lin et al. 2003). We postulate that the $10-11 \mathrm{Ma}$ zircon belong to this magmatic event although a Luzon arc affinity cannot be discarded.

Previous estimates for the maximum deposit age of the Yuli belt are as young as $15.4 \pm 0.4 \mathrm{Ma}$ based on the youngest weighted mean U-Pb zircon age (Chen et al. 2017) of the volcanic island arc affinity (Sun et al. 1998) Tamayen's HP block enclosed in the Yuli metapelitic sediments. The blocks' age certainly predates the deposition of the surrounding matrix and indeed provides a maximum depositional age. Chen et al. (2017) also found 3 zircon grain aged between $\sim 10-11 \mathrm{Ma}$ in the northern Yuli belt samples (Fig. 2c) further arguing for similar sedimentary source and age of deposition with the Chulai Formation. The contact between the Chulai Formation and Yuli is sharp and strongly deformed with no evidence of faulting (Fig. 5 in Stanley et al. 1981) suggesting the contact to be depositional. The non-faulted nature of the contact was further confirmed by field work carried out by the authors in the exact locality where it was defined (Stop 2 of Stanley et al. 1981), and the same three sets of schistosities were recognised above and below the contact (unpublished work).

Overall, the Yuli belt and Chulai Formation (1) are separated by a depositional contact (2) share the same continental affinity zircon U-Pb age populations, (3) have undergone the same deformation history. Taken together, these pieces of evidences favour a relatively continuous sedimentary succession subsequently deformed in the orogeny (i.e., post $11.2 \pm 0.2 \mathrm{Ma}$ ). It also argues against Stanley et al. (1981) interpretation of the Chulai Formation being a forearc unit partly deposited on top of the early accretionary wedge, although the widespread Miocene zircons cannot be excluded to be sourced from the Luzon volcanic arc, and thus a Philippine Sea plate affinity cannot be totally discarded. Considering the maximum deposition time for the Yuli belt is limited to $\sim 15-11 \mathrm{Ma}$ and that the Chulai Formation's metamorphic temperature is lower, we suggest that the Chulai Formation could represent stratigraphically younger sediments occupying the higher structural levels of a relatively continuous deformed rocks succession.

However, we would like to stress that although we argue for a stratigrpahically coherent sedimentary succession between the Yuli belt sediments and Chulai Formation, they do present different lithologies and maximum metamorphic temperatures, an apparent contradiction that deserve further work to be fully elucidated. Notably the nature of the depositional contact (i.e., nonconformity? angular unconformity?) is critical to understand the timing of the initial stage of deformation in the Central Range. Similarly, since we cannot totally discard a recycled nature for the Chulai Fm (i.e., derived from the Yuli units), an improved understanding of the depositional setting (e.g., passive margin $v s$. forearc $v s$. wedge top) could further provide fundamental constraints.

In any case, the Chulai Formation appears to be the youngest pervasively deformed and metamorphosed sediments in the Central Range and can tentatively be correlated to the unmetamorphosed upper Miocene sediments of the southernmost tip of Taiwan (Mudan Fm.) or to the upper Miocene sediments outcropping in the Western Foothills (Nanchuang Fm.).

\subsection{Considerations on the Timing of the Yuli Belt Metamorphism}

The onset of subduction related metamorphism in the Taiwan orogen is a long lasting debate. On the one hand the older ${ }^{40} \mathrm{Ar} /{ }^{39} \mathrm{Ar}$ plateau and intercept ages in white mica, omphacite and amphibole in the Yuli belt HP blocks suggest $\sim 10-12 \mathrm{Ma}$ as the start of metamorphism (Lo and Yui 1996; Chen et al. 2019). In the other hand, Sandmann et al. (2015) argued that ${ }^{40} \mathrm{Ar} /{ }^{39} \mathrm{Ar}$ ages may have been compromised by a well described process of excess Argon in highpressure rocks (e.g., Kelley 2002; and discussion in Lo and Yui 1996), and that garnet Lu-Hf dating really reflected the age of near-peak metamorphic conditions at $5.1 \pm 1.7 \mathrm{Ma}$. This finding is consistent with fine grained fraction $(<2 \mu \mathrm{m})$ of presumably neoformed white micas ${ }^{40} \mathrm{~K} /{ }^{39} \mathrm{Ar}$ ages of $\sim 5$ - $8 \mathrm{Ma}$ in Yuli belt matrix (Tsao 1996) and with the lowest temperature steps ${ }^{40} \mathrm{Ar} /{ }^{39} \mathrm{Ar}$ ages on muscovite and plateau ${ }^{40} \mathrm{Ar} /{ }^{39} \mathrm{Ar}$ ages on biotite of $\sim 6-9$ Ma recorded in some Taroko basement intrussives (Lo and Onstott 1995).

The peak metamorphic temperature in the Chulai Formation is $\sim 370^{\circ} \mathrm{C}$ (Beyssac et al. 2007). Such a temperature is higher than the temperatures underwent by the Eocene 
sedimentary cover of the Central Range, and considering that the sedimentary thickness on top of the Chulai Formation is unlikely over $10 \mathrm{~km}$ since deposition $(<11.2 \pm 0.2 \mathrm{Ma}$; this study), the peak metamorphic temperature can rather be interpreted to result from a subduction related burial.

One significant contribution of the present work is that our maximum depositional age provides the upper limit for metamorphism and the main phases of deformation in the Central Range to $\leq 11.2 \pm 0.2 \mathrm{Ma}$. Combined with the above considered chronological constraints, it seems to disprove an early onset of mountain building at $\sim 12 \mathrm{Ma}$ (Teng 1990; Chen et al. 2019) since deformation and metamorphism of the Chulai Formation could not have started before deposition, and rather support a younger onset of metamorphism. Considering the oldest fission tracks cooling ages of 6 $7 \mathrm{Ma}$ (Liu et al. 2001; Mesalles et al. 2014; Lee et al. 2015), Tailuko belt's granitic intrusion biotite ${ }^{40} \mathrm{Ar} /{ }^{39} \mathrm{Ar}$ ages $(\sim 7.7$ $\mathrm{Ma})$, white mica lower temperature steps ${ }^{40} \mathrm{Ar} /{ }^{39} \mathrm{Ar}$ ages ( 6 - 9 Ma) (Lo and Onstott 1995) and foreland flexure onset at $\sim 6.5 \mathrm{Ma}$ (Lin et al. 2003), we suggest the onset of metamorphism and mountain building to have occurred at $\sim 6-8 \mathrm{Ma}$.

In addition, the end of rifting related magmatism at 8 - 9 Ma (Chung et al. 1994, 1995) in western Taiwan appears to be closely followed by what is here interpreted as the initial subduction related metamorphism. The narrow temporal gap between both events can be explained by high convergence rates of $82 \mathrm{~cm} \mathrm{yr}^{-1}$ (present day convergence; $\mathrm{Yu}$ et al. 1997) where in $1 \mathrm{Myr}$ about $80-90 \mathrm{~km}$ of oceanic crust could be consumed in the subduction zone. Such a short duration burial and exhumation path falls in what has been described as very short duration metamorphism (Viete and Lister 2017).

\section{CONCLUSION}

The main contributions of this paper can be summarized in the following three points:

(1) The Chulai Formation, traditionally considered of Eocene age, is here demonstrated to have a Late Miocene (Tortonian) maximum depositional age $(<11.2 \pm$ $0.2 \mathrm{Ma}$ ) with a zircon age spectrum that is unlike the age spectrum of the Eocene sediments. The Chulai Formation is thus the youngest metamorphic unit preserved in the Central Range.

(2) Considering that the Chulai Formation is in depositional contact with the underlying Yuli belt and displays the same deformation history, we postulate that $11.2 \pm$ $0.2 \mathrm{Ma}$ is the upper limit for the main Cenozoic deformation and metamorphic events. Existing geochronological constraints suggests that the probable age of metamorphism is $\sim 6-8 \mathrm{Ma}$.

(3) The Chulai Formation yields a dominant continental detrital zircon suite strikingly similar with the Yuli belt's one, indicating a common continental source and a prob- ably similar or slightly younger depositional age.

Acknowledgements We acknowledge funding from the Integrated Study on Seismotectonic Models for Typical Regions (grant number F-18-04) to XBT and the Taiwan's Ministry of Science and Technology project MOST-1072811-M-194-008 to YHL and LM. We would like to thank Tim Byrne, two anonymous reviewers and editor Ruey-Juin Rau for their comments that improved the initial manuscript.

\section{REFERENCES}

Barham, M., C. L. Kirkland, and J. Hollis, 2019: Spot the difference: Zircon disparity tracks crustal evolution. Geology, 47, 435-439, doi: 10.1130/G45840.1. [Link]

Baziotis, I., C.-H. Tsai, W. G. Ernst, B.-M. Jahn, and Y. Iizuka, 2017: New $P-T$ constraints on the Tamayen glaucophane-bearing rocks, eastern Taiwan: Perple_X modelling results and geodynamic implications. $J$. Metamorph. Geol., 35, 35-54, doi: 10.1111/jmg.12218. [Link]

Beyssac, O., M. Simoes, J. P. Avouac, K. A. Farley, Y.-G. Chen, Y.-C. Chan, and B. Goffé, 2007: Late Cenozoic metamorphic evolution and exhumation of Taiwan. Tectonics, 26, doi: 10.1029/2006TC002064. [Link]

Beyssac, O., F. Negro, M. Simoes, Y. C. Chan, and Y. G. Chen, 2008: High-pressure metamorphism in Taiwan: From oceanic subduction to arc-continent collision? Terr. Nova, 20, 118-125, doi: 10.1111/j.13653121.2008.00796.x. [Link]

Biq, C., 1974: Taiwan. Geol. Soc. London, Spec. Publ., 4, 501-511, doi: 10.1144/GSL.SP.2005.004.01.32. [Link]

CGS, 1974: Geologic Map of Taiwan - 1:250,000, Central Geological Survey, The Ministry of Economic Affairs, Taipei, Taiwan.

CGS, 1978: Tectonic Map of Taiwan 1:500,000, Central Geological Survey, The Ministry of Economic Affairs, Taipei, Taiwan.

Chen, C.-H., H.-T. Chu, J.-G. Liou, and W. G. Ernst, 1983: Explanatory Notes for the Metamorphic Facies Map of Taiwan, Central Geological Survey, Taipei, Taiwan.

Chen, C.-H., H.-C. Ho, K.-S. Shea, W. Lo, W.-H. Lin, H.C. Chang, C.-W. Huang, C.-N. Yang, and Y.-H. Lee, 2000: Geological Map of Taiwan - 1:1,000,000 Scale, Central Geological Survey, Taipei, Taiwan.

Chen, W.-S., 2016: Introduction to Taiwan Geology, 1st Edition, Geological Society of Taiwan, Taipei City, Taiwan, $250 \mathrm{pp}$.

Chen, W.-S., Y.-C. Huang, C.-H. Liu, H.-T. Feng, S.-L. Chung, and Y.-H. Lee, 2016: U-Pb zircon geochronology constraints on the ages of the Tananao Schist Belt and timing of orogenic events in Taiwan: Implications for a new tectonic evolution of the South China Block during the Mesozoic. Tectonophysics, 686, 68-81, doi: 
10.1016/j.tecto.2016.07.021. [Link]

Chen, W.-S., S.-L. Chung, H.-Y. Chou, Z. Zugeerbai, W.Y. Shao, and Y.-H. Lee, 2017: A reinterpretation of the metamorphic Yuli belt: Evidence for a middle-late Miocene accretionary prism in eastern Taiwan. Tectonics, 36, 188-206, doi: 10.1002/2016TC004383. [Link]

Chen, W.-S., J.-J. Yeh, and S.-J. Syu, 2019: Late Cenozoic exhumation and erosion of the Taiwan orogenic belt: New insights from petrographic analysis of foreland basin sediments and thermochronological dating on the metamorphic orogenic wedge. Tectonophysics, 750, 56-69, doi: 10.1016/j.tecto.2018.09.003. [Link]

Ching, K.-E., M.-L. Hsieh, K. M. Johnson, K.-H. Chen, R.-J. Rau, and M. Yang, 2011: Modern vertical deformation rates and mountain building in Taiwan from precise leveling and continuous GPS observations, 2000-2008. J. Geophys. Res., 116, doi: 10.1029/2011JB008242. [Link]

Chu, X., J. J. Ague, Y. Y. Podladchikov, and M. Tian, 2017: Ultrafast eclogite formation via melting-induced overpressure. Earth Planet. Sci. Lett., 479, 1-17, doi: 10.1016/j.eps1.2017.09.007. [Link]

Chung, L.-H., Y.-H. Lee, W.-L. Tsai, K.-S. Shea, L. S. Teng, W. Lo, and X.-B. Tan, 2018: Refining stratigraphic ages of Northern Hsuehshan Range in northern Taiwan by detrital zircon U-Pb dating. Terr. Atmos. Ocean. Sci., 29, 291-300, doi: 10.3319/TAO.2017.10.19.01. [Link]

Chung, S.-L., S. Sun, K. Tu, C.-H. Chen, and C. Lee, 1994: Late Cenozoic basaltic volcanism around the Taiwan Strait, SE China: Product of lithosphere-asthenosphere interaction during continental extension. Chem. Geol., 112, 1-20, doi: 10.1016/0009-2541(94)90101-5. [Link]

Chung, S.-L., B.-M. Jahn, S.-J. Chen, T. Lee, and C.-H. Chen, 1995: Miocene basalts in northwestern Taiwan: Evidence for EM-type mantle sources in the continental lithosphere. Geochim. Cosmochim. Acta, 59, 549555, doi: 10.1016/0016-7037(94)00360-X. [Link]

Deng, K., S. Yang, C. Li, N. Su, L. Bi, Y.-P. Chang, and S.-C. Chang, 2017: Detrital zircon geochronology of river sands from Taiwan: Implications for sedimentary provenance of Taiwan and its source link with the east China mainland. Earth-Sci. Rev., 164, 31-47, doi: 10.1016/j.earscirev.2016.10.015. [Link]

Dickinson, W. R. and G. E. Gehrels, 2009: Use of U-Pb ages of detrital zircons to infer maximum depositional ages of strata: A test against a Colorado Plateau Mesozoic database. Earth Planet. Sci. Lett., 288, 115-125, doi: 10.1016/j.eps1.2009.09.013. [Link]

Ho, C.-S., 1986: A synthesis of the geologic evolution of Taiwan. Tectonophysics, 125, 1-16, doi: 10.1016/00401951(86)90004-1. [Link]

Ho, C.-S., 1988: An Introduction to the Geology of Taiwan: Explanatory Text of the Geologic Map of Taiwan, Sec- ond Edition, Central Geological Survey, The Ministry of Economic Affairs, Taipei, Taiwan.

Hsu, W.-H., T. B. Byrne, W. Ouimet, Y.-H. Lee, Y.-G. Chen, M. van Soest, and K. Hodges, 2016: Pleistocene onset of rapid, punctuated exhumation in the eastern Central Range of the Taiwan orogenic belt. Geology, 44, 719-722, doi: 10.1130/G37914.1. [Link]

Jackson, S. E., N. J. Pearson, W. L. Griffin, and E. A. Belousova, 2004: The application of laser ablation-inductively coupled plasma-mass spectrometry to in situ U-Pb zircon geochronology. Chem. Geol., 211, 47-69, doi: 10.1016/j.chemgeo.2004.06.017. [Link]

Jahn, B.-M., J.-G. Liou, and H. Nagasawa, 1981: Highpressure metamorphic rocks of Taiwan - REE geochemistry, $\mathrm{Rb}-\mathrm{Sr}$ ages and tectonic implications. Mem. Geol. Soc. China, 4, 497-520.

Kelley, S., 2002: Excess argon in K-Ar and Ar-Ar geochronology. Chem. Geol., 188, 1-22, doi: 10.1016/S00092541(02)00064-5. [Link]

Keyser, W., C.-H. Tsai, Y. Iizuka, R. Oberhänsli, and W. G. Ernst, 2016: High-pressure metamorphism in the Chinshuichi area, Yuli belt, eastern Taiwan. Tectonophysics, 692, 191-202, doi: 10.1016/j.tecto.2015.09.012. [Link]

Kirstein, L. A., M. G. Fellin, S. D. Willett, A. Carter, Y.-G. Chen, J. I. Garver, and D. C. Lee, 2010a: Pliocene onset of rapid exhumation in Taiwan during arc-continent collision: New insights from detrital thermochronometry. Basin Res., 22, 270-285, doi: 10.1111/j.13652117.2009.00426.x. [Link]

Kirstein, L. A., A. Carter, and Y .-G. Chen, 2010b: Testing inferences from palaeocurrents: Application of zircon double-dating to Miocene sediments from the Hengchun Peninsula, Taiwan. Terr. Nova, 22, 483-493, doi: 10.1111/j.1365-3121.2010.00970.x. [Link]

Kohn, M. J. and N. M. Kelly, 2017: Petrology and Geochronology of Metamorphic Zircon. In: Moser, D. E., F. Corfu, J. R. Darling, S. M. Reddy, and K. Tait (Eds.), Microstructural Geochronology: Planetary Records Down to Atom Scale, Geophysical Monograph Series 232, American Geophysical Union, 35-61, doi: 10.1002/9781119227250.ch2. [Link]

Lan, C.-Y., T. Usuki, K.-L. Wang, T.-F. Yui, K. Okamoto, Y.-H. Lee, T. Hirata, Y. Kon, Y. Orihashi, J. G. Liou, and C.-S. Lee, 2009: Detrital zircon evidence for the antiquity of Taiwan. Geosci. J., 13, 233-243, doi: 10.1007/s12303-009-0023-3. [Link]

Lee, Y.-H., C.-C. Chen, T.-K. Liu, H.-C. Ho, H.-Y. Lu, and W. Lo, 2006: Mountain building mechanisms in the Southern Central Range of the Taiwan Orogenic Belt - From accretionary wedge deformation to arc-continental collision. Earth Planet. Sci. Lett., 252, 413-422, doi: 10.1016/j.epsl.2006.09.047. [Link]

Lee, Y.-H., T. Byrne, W.-H. Wang, W. Lo, R.-J. Rau, and 
H.-Y. Lu, 2015: Simultaneous mountain building in the Taiwan orogenic belt. Geology, 43, 451-454, doi: 10.1130/G36373.1. [Link]

Lin, A. T., A. B. Watts, and S. P. Hesselbo, 2003: Cenozoic stratigraphy and subsidence history of the South China Sea margin in the Taiwan region. Basin Res., 15, 453478, doi: 10.1046/j.1365-2117.2003.00215.x. [Link]

Lin, C.-W. and W.-S. Chen, 2016: Geologic Map of Taiwan, Geological Society of Taiwan, Taipei, Taiwan, Republic of China.

Lin, M.-L., 1999: Litho-stratigraphy and structural geology of the Wanjung area, eastern Taiwan and their tectonic implications. J. Geol. Soc. China, 42, 247-267.

Liou, J.-G., 1981: Petrology of metamorphosed oceanic rocks in the Central Range of Taiwan. Mem. Geol. Soc. China, 4, 291-341.

Liu, T.-K., S. Hsieh, Y.-G. Chen, and W.-S. Chen, 2001: Thermo-kinematic evolution of the Taiwan obliquecollision mountain belt as revealed by zircon fission track dating. Earth Planet. Sci. Lett., 186, 45-56, doi: 10.1016/S0012-821X(01)00232-1. [Link]

Lo, C.-H. and T. C. Onstott, 1995: Rejuvenation of $\mathrm{K}-\mathrm{Ar}$ systems for minerals in the Taiwan Mountain Belt. Earth Planet. Sci. Lett., 131, 71-98, doi: 10.1016/0012-821X(95)00011-Z. [Link]

Lo, C.-H. and T.-F. Yui, 1996: ${ }^{40} \mathrm{Ar} /{ }^{39} \mathrm{Ar}$ dating of highpressure rocks in the Tananao basement complex, Taiwan. J. Geol. Soc. China, 39, 13-30.

Lo, Y.-C., C.-T. Chen, C.-H. Lo, and S.-L. Chung, 2020: Ages of ophiolitic rocks along plate suture in Taiwan orogen: Fate of the South China Sea from subduction to collision. Terr. Atmos. Ocean. Sci., 31, 383-402, doi: 10.3319/TAO .2019.06.19.01. [Link]

Ludwig, K. R., 1998: On the treatment of concordant uranium-lead ages. Geochim. Cosmochim. Acta, 62, 665676, doi: 10.1016/s0016-7037(98)00059-3. [Link]

Mesalles, L., F. Mouthereau, M. Bernet, C.-P. Chang, A. T. S. Lin, C. Fillon, and X. Sengelen, 2014: From submarine continental accretion to arc-continent orogenic evolution: The thermal record in southern Taiwan. Geology, 42, 907-910, doi: 10.1130/G35854.1. [Link]

Ooe, Z., M. Haruta, and T. Suzuki, 1939: Taito Map. Geological Map of Taiwan and Explanatory Text Scale 1:100,000, Geological Sheet n18, Bureau of Productive Industries, Governement General of Taiwan, Japan.

Sandmann, S., T. J. Nagel, N. Froitzheim, K. Ustaszewski, and C. Münker, 2015: Late Miocene to Early Pliocene blueschist from Taiwan and its exhumation via forearc extraction. Terr. Nova, 27, 285-291, doi: 10.1111/ ter.12158. [Link]

Shao, L., L. Cao, P. Qiao, X. Zhang, Q. Li, and D. J. van Hinsbergen, 2017: Cretaceous-Eocene provenance connections between the Palawan Continental Terrane and the northern South China Sea margin.
Earth Planet. Sci. Lett., 477, 97-107, doi: 10.1016/j. eps1.2017.08.019. [Link]

Sláma, J., J. Košler, D. J. Condon, J. L. Crowley, A. Gerdes, J. M. Hanchar, M. S. A. Horstwood, G. A. Morris, L. Nasdala, N. Norberg, U. Schaltegger, B. Schoene, M. N. Tubrett, and M. J. Whitehouse, 2008: Plešovice zircon - A new natural reference material for $\mathrm{U}-\mathrm{Pb}$ and Hf isotopic microanalysis. Chem. Geol., 249, 1-35, doi: 10.1016/j.chemgeo.2007.11.005. [Link]

Spencer, C. J., C. L. Kirkland, and R. J. M. Taylor, 2016: Strategies towards statistically robust interpretations of in situ U-Pb zircon geochronology. Geosci. Front., 7, 581-589, doi: 10.1016/j.gsf.2015.11.006. [Link]

Stanley, R. S., L. B. Hill, H. C. Chang, and H.-N. Hu, 1981: A transect through the metamorphic core of the central mountains, southern Taiwan. Mem. Geol. Soc. China, 4, 443-473.

Sun, C.-H., A. D. Smith, and C.-H. Chen, 1998: Nd$\mathrm{Sr}$ isotopic and geochemical evidence on the protoliths of exotic blocks in the Juisui area, Yuli belt, Taiwan. Int. Geol. Rev., 40, 1076-1087, doi: 10.1080/00206819809465255. [Link]

Teng, L. S., 1990: Geotectonic evolution of late Cenozoic arc-continent collision in Taiwan. Tectonophysics, $\mathbf{1 8 3}$, 57-76, doi: 10.1016/0040-1951(90)90188-e. [Link]

Tsai, C.-H., Y. Iizuka, and W. G. Ernst, 2013: Diverse mineral compositions, textures, and metamorphic P-T conditions of the glaucophane-bearing rocks in the Tamayen mélange, Yuli belt, eastern Taiwan. J. Asian Earth Sci., 63, 218-233, doi: 10.1016/j.jseaes.2012.09.019. [Link]

Tsao, S.-J., 1996: The geological significance of illite crystallinity, zircon fission-track ages and K-Ar ages of metasedimentary rocks of the Central Range. Master Thesis, National Taiwan University, Taipei, Taiwan, $272 \mathrm{pp}$.

Vermeesch, P., 2012: On the visualisation of detrital age distributions. Chem. Geol., 312-313, 190-194, doi: 10.1016/j.chemgeo.2012.04.021. [Link]

Vermeesch, P., 2018a: Dissimilarity measures in detrital geochronology. Earth-Sci. Rev., 178, 310-321, doi: 10.1016/j.earscirev.2017.11.027. [Link]

Vermeesch, P., 2018b: IsoplotR: A free and open toolbox for geochronology. Geosci. Front., 9, 1479-1493, doi: 10.1016/j.gsf.2018.04.001. [Link]

Viete, D. R. and G. S. Lister, 2017: On the significance of short-duration regional metamorphism. J. Geol. Soc., 174, 377-392, doi: 10.1144/jgs2016-060. [Link]

Viete, D. R., B. R. Hacker, M. B. Allen, G. G. E. Seward, M. J. Tobin, C. S. Kelley, G. Cinque, and A. R. Duckworth, 2018: Metamorphic records of multiple seismic cycles during subduction. Sci. Adv., 4, eaaq0234, doi: 10.1126/sciadv.aaq0234. [Link]

Willett, S. D., D. Fisher, C. Fuller, E.-C. Yeh, and C.-Y. Lu, 
2003: Erosion rates and orogenic-wedge kinematics in Taiwan inferred from fission-track thermochronometry. Geology, 31, 945-948, doi: 10.1130/G19702.1. [Link]

Yang, C.-N. and Y. Wang, 1985: Petrotectonic study on the Yuli belt of the Tananao Schist in the Juisui area, eastern Taiwan. Science Reports of the National Taiwan University, ACTA Geologica Taiwanica, 23, 153-180.

Yu, S.-B., H.-Y. Chen, and L.-C. Kuo, 1997: Velocity field of GPS stations in the Taiwan area. Tectonophysics, 274, 41-59, doi: 10.1016/S0040-1951(96)00297-1. [Link]
Yui, T. F., K. Okamoto, T. Usuki, C. Y. Lan, H. T. Chu, and J. G. Liou, 2009: Late Triassic-Late Cretaceous accretion/subduction in the Taiwan region along the eastern margin of South China - Evidence from zircon SHRIMP dating. Int. Geol. Rev., 51, 304-328, doi: 10.1080/00206810802636369. [Link]

Yui, T. F., K. Maki, C. Y. Lan, T. Hirata, H. T. Chu, Y. Kon, T. D. Yokoyama, B. M. Jahn, and W. G. Ernst, 2012: Detrital zircons from the Tananao metamorphic complex of Taiwan: Implications for sediment provenance and Mesozoic tectonics. Tectonophysics, 541-543, 3142, doi: 10.1016/j.tecto.2012.03.013. [Link] 